\title{
LALINET STATUS - STATION EXPANSION AND LIDAR RATIO SYSTEMATIC MEASUREMENTS
}

Eduardo Landulfo $^{1, *}$, Fabio Lopes ${ }^{1}$, Gregori Arruda Moreira ${ }^{1}$, Jonatan da Silva ${ }^{1}$, Pablo

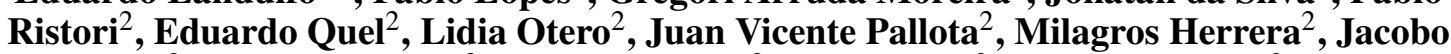
Salvador $^{2}$, Juan Lucas Bali ${ }^{2}$, Eliam Wolfram ${ }^{2}$, Paula Etala ${ }^{3}$, Albane Barbero ${ }^{3}$, Ricardo Forno $^{4}$, Maria Fernanda Sanchez ${ }^{4}$, Henrique Barbosa ${ }^{5}$, Diego Gouveia ${ }^{5}$, Amanda Vieira Santos $^{5}$, Judith Hoelzemann ${ }^{6}$, Jose Henrique Fernandez ${ }^{6}$, Anderson Guedes ${ }^{6}$, Antonieta Silva $^{7,8}$, Boris Barja ${ }^{9}$, Felix Zamorano ${ }^{9}$, Raul Perez Legue ${ }^{9}$, Alvaro Bastidas ${ }^{10}$, Maribel Vellejo Zabala ${ }^{10}$, Juan Velez ${ }^{10}$, Daniel Nisperuza ${ }^{10}$, Elena Montilla ${ }^{11}$, Rene Estevam Arredondo $^{12}$, Juan Carlos Antuña Marrero ${ }^{12}$, Alberth Rodriguez Vega ${ }^{12}$, Lucas Alados-Arboledas $^{13,14}$, Juan Luis Guerrero-Rascado ${ }^{13,14}$, Nobuo Sugimoto ${ }^{15}$ and Jin Yoshitaka $^{15}$

${ }^{1}$ Instituto de Pesquisas Energéticas e Nucleares, Centro de Lasers e Aplicações, Av. Prof. Lineu Prestes, 2242, São Paulo, 05508000, Brazil, *elandulf@ipen.br

${ }^{2}$ CITEDEF, CEILAP, San Juan Bautista de la Salle 4397, Buenos Aires, B1603ALO, Argentina

${ }^{3}$ Servicio Meteorologico Nacional, 25 de Mayo 658, C1002ABN CABA, Argentina

${ }^{4}$ Laboratorio de Física de la Atmosfera, Universidad Mayor de San Andrés, La Paz, Bolivia

${ }^{5}$ Dep. de Fisica Aplicada, U. de São Paulo, Rua do Matão, 1371, 05508-090, São Paulo, Brazil

${ }^{6}$ CCET, U. Federal do Rio Grande do Norte, Av Sen Salgado Filho, 59078900, RN, Brazil

${ }^{7}$ Center for Optics and Photonics (CEFOP), Universidad de Concepción-Chile

${ }^{8}$ Departamento de Ciencias Físicas, Universidad de La Frontera, Temuco, Chile

${ }^{9}$ Atmospheric Research Laboratory (LIA), UMAG, Punta Arenas, Chile

${ }^{10}$ Grupo de Investigación Láseres y Espectroscopia, Universidad Nacional de Colombia, Medellín, Colombia

${ }^{11}$ Escuela de Ciencias, Universidad EAFIT, Medellín, Colombia

${ }^{12}$ Grupo de Óptica Atmosférica de Camagüey, CMC, INSMET, Cuba

${ }^{13}$ Andalusian Institute for Earth System Research (IISTA-CEAMA), Spain

${ }^{14}$ Dpt. Applied Physics, Faculty of Sciences, University of Granada, Spain

${ }^{15}$ National Institute for Environmental Studies, Tsukuba, Japan

\begin{abstract}
LALINET is expanding regionally to guarantee spatial coverage over South and Central Americas. One of the network goals is to obtain a set of regional representative aerosol optical properties such as particle backscatter, extinction and lidar ratio. Given the North-South extension and influence of distinct airmass circulation patterns it is paramount to distinguish these optical parameters in order to gain better perfomance in radiation transfer models. A set of lidar ratio data is presented.
\end{abstract}

\section{INTRODUCTION}

Latin America Lidar Network is a federative fully operative lidar for aerosol research in
South and Central America. Its operational cycle concerns probing the atmosphere on regular basis to retrieve vertically and temporally resolved aerosol optical and microphysical properties(Luis Guerrero-Rascado et al., 2016). Most of the instruments based in the network were customized and produced configurations suitable for the aerosol observation task. The network was officially established in 2013 by recognition as being part of GAW-GALION programs under the supervision of World Meteorological Organization(Antuña-Marrero et al., 2016). The present goals of LALINET are:

1. Consolidate the measurement and data acquisition protocols 
2. Establish a QA/QC routine among all stations

3. Improve and establish an unified data analysis routine common to all stations, e.g., Single Calculus Chain(D'Amico et al., 2015)

4. Create a scientifically signficant distributed database,e.g., lidar ratio, particle extinction, backscatter, angstrom exponents and particle depol. regional values

5. Guarantee the continuity of LALINET's biannual workshops by the intensification its role as a mechanism of transfer of knowledge, evaluation of joint actions conducted and agreemnts on how to continue under the new evolving situations. In 2018 second semester, the host site should be in Medellin, Colombia

Yet regarding the vast majority of stations share a collocated AERONET station the use of the GRASP approach is also envisaged(Torres et al., 2016) in order to obtain particle microphysical properties. Currently LALINET is seeking its expansion to better cover up a region roughly twice the size of EARLINET(Mona, L. et al., 2016) and therefore a region where more circulation patterns take place. A careful establishment of a regional distributed aerosol optical parameter database pose a challenge wich could be tackled with the network expansion. In this matter 2 stations were deployed as seen in table 1. One in Natal, Brazil, which should be focused on long-range aerosol transport from Saharan dust. The other in Punta Arenas in Chile, which is also part of SAVER.NET(Quel, Eduardo et al., 2016) which merges the efforts of LALINET and AD-NET(Nishizawa, Tomoaki et al., 2016).

\subsection{LALINET Lidar Stations}

Up to date there are 14 operative stations, see Table 1, distributed along the South american continent. The vast majority has collocated AERONET sunphotometer stations which helps in the lidar data retrieval of the lidar ratio by means of a closure between the two instruments and further on the implementation of data integration algorithms such as GRASP.

\section{METHODOLOGY}

LALINET measurement protocol follows an twice a week measurements on Mondays and Thursdays, even though pne station operates continuously (MAO) and with other schedules for other proposes. The products obtained are aerosol backscattering and extinction profiles, Lidar ratios (average and profiles when raman channels are operative). Since the vast majority of stations have collocated AERONET sunphotometers it is possible to obtain microphysical products. Some of the station also have polarization-sensitive channels which allows information on shape and identification of aerosols.

\section{RESULTS}

\subsection{Calbuco Eruption}

On April 22, 2015, the Calbuco volcano in Chile $\left(41.33^{\circ} \mathrm{S}, 72.62^{\circ} \mathrm{W}\right)$ erupted after 43 years of inactivity, followed by an injection of pyroclastic material dispersed into the atmosphere on weeks after the event. At first a threat-alarm to aviation traffic and air quality over a large area was released, and the stations on the southermost part of SA were triggered on daily monitoring basis in Argentina, Brazil, and Chile. Below we find a temporal serie of range corrected signal at $532 \mathrm{~nm}$ the quick look of the 
Table 1: LALINET Lidar Stations - The boxes in green are newly added stations in 2016. *Temuco station is the previous Concepcion Station.

\begin{tabular}{|c|c|c|c|}
\hline ST. & ID & $\begin{array}{c}\operatorname{LAT}(\mathbf{S}) \\
\operatorname{LON}(\mathbf{W})\end{array}$ & $\begin{array}{c}\text { Channels } \\
\text { (nm) }\end{array}$ \\
\hline $\begin{array}{c}\text { Buenos } \\
\text { Aires }\end{array}$ & $A E P$ & $\begin{array}{l}34.56^{\circ} \mathrm{S} \\
58.42^{\circ} \mathrm{W}\end{array}$ & $\begin{array}{c}1064,532^{p} \\
\& 355^{p}\end{array}$ \\
\hline $\begin{array}{c}\text { Buenos } \\
\text { Aires }\end{array}$ & $V M A$ & $\begin{array}{l}34.56^{\circ} \mathrm{S} \\
58.51^{\circ} \mathrm{W}\end{array}$ & $\begin{array}{c}1064,607 \\
532^{p}, 387 \\
\& 355^{p}\end{array}$ \\
\hline Neuquen & $N Q N$ & $\begin{array}{l}38.95^{\circ} \mathrm{S} \\
68.13^{\circ} \mathrm{W}\end{array}$ & $\begin{array}{c}1064,532^{p} \\
\& 355^{p}\end{array}$ \\
\hline $\begin{array}{c}\text { Barilo- } \\
\text { che }\end{array}$ & $B R C$ & $\begin{array}{l}41.15^{\circ} \mathrm{S} \\
71.16^{\circ} \mathrm{W}\end{array}$ & $\begin{array}{c}1064,607 \\
532,387 \\
\& 355\end{array}$ \\
\hline $\begin{array}{c}\text { Commo } \\
\text { doro }\end{array}$ & $C D R$ & $\begin{array}{l}45.79^{\circ} \mathrm{S} \\
67.46^{\circ} \mathrm{W}\end{array}$ & $\begin{array}{c}1064,532 \\
\& 355\end{array}$ \\
\hline $\begin{array}{l}\text { Gal- } \\
\text { legos }\end{array}$ & $R G L$ & $\begin{array}{l}51.61^{\circ} \mathrm{S} \\
69.31^{o} \mathrm{~W}\end{array}$ & $\begin{array}{c}1064,532^{p} \\
\& 355^{p}\end{array}$ \\
\hline $\begin{array}{l}\text { Punta } \\
\text { Arenas }\end{array}$ & $P A R^{*}$ & $\begin{array}{l}53.13^{\circ} \mathrm{S} \\
70.88^{\circ} \mathrm{W}\end{array}$ & $\begin{array}{l}1064,607, \\
532^{p}, 408, \\
387 \& 355^{p}\end{array}$ \\
\hline $\begin{array}{c}\text { S. } \\
\text { Paulo }\end{array}$ & $S P U$ & $\begin{array}{l}23^{\circ} 13^{\prime} \\
46^{\circ} 28^{\prime}\end{array}$ & $\begin{array}{c}1064,607 \\
532,408, \\
387 \& 355\end{array}$ \\
\hline $\begin{array}{c}\text { S. } \\
\text { Paulo }\end{array}$ & $S P T$ & $V A R$ & 607,532 \\
\hline $\begin{array}{c}\text { Man- } \\
\text { aus }\end{array}$ & $M A O$ & $\begin{array}{l}02.60^{\circ} \mathrm{S} \\
60.21^{\circ} \mathrm{W}\end{array}$ & $\begin{array}{c}408, \\
387,355\end{array}$ \\
\hline Natal & $N A T$ & $\begin{array}{l}05.82^{\circ} \mathrm{S} \\
35.20^{\circ} \mathrm{W}\end{array}$ & $\begin{array}{c}1064,532^{p} \\
\& 355^{p}\end{array}$ \\
\hline Тетисо * & $T M U^{*}$ & $\begin{array}{l}38.74^{\circ} \mathrm{S} \\
72.62^{\circ} \mathrm{W}\end{array}$ & $\begin{array}{c}1064,532^{p} \\
\& 355^{p}\end{array}$ \\
\hline Medellin & $M E D$ & $\begin{array}{l}06.26^{\circ} \mathrm{N} \\
75.58^{\circ} \mathrm{W}\end{array}$ & $532 \& 355$ \\
\hline La Paz & $L P Z$ & $\begin{array}{l}16.54^{\circ} \mathrm{S} \\
68.07^{\circ} \mathrm{W}\end{array}$ & $\begin{array}{c}1064,532^{p} \\
\& 355^{p}\end{array}$ \\
\hline
\end{tabular}

lidar measurements conducted at AEP station, in Buenos Aires, Argentina. The volcanic layer detected on April 24 shows a persistency along the entire day ranging between 5 and $7 \mathrm{~km}$ Later on there is a subsidency of this layer not mixing however with the urban mixing layer below the PBL around $1.5-2.0 \mathrm{~km}$. This station, to the east of the Calbuco, measured a tropospheric aerosol layer at about $6 \mathrm{~km}$ a.g.l. which subsided along the day of measurement.

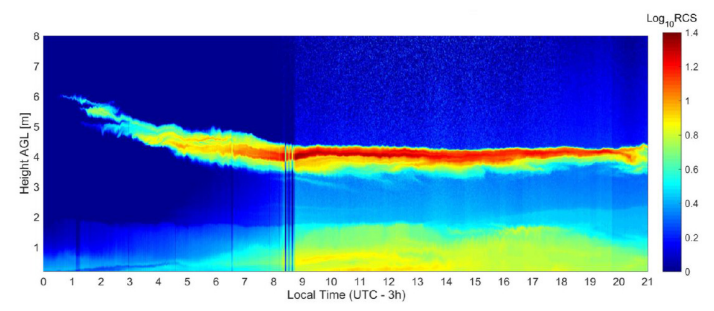

Figure 1: RCS quicklook obtained by AEP station, in Buenos Aires, Argentina, 2 days after the

Calbuco Eruption allowing a consistent tracking of the pyroclastic material ejected by the volcano spreading over south of South America.

\subsection{Lidar Ratio Evaluation}

Aiming to create a consistent lidar ratio climatology regionally distributed we have evaluated the yearly mean values of some LALINET stations which included the results obtained from procotol measurements taken routineously. Some of the values are from intensive campaigns taken previously (BUE and PAR) using lidar/sunphotometer sinergy in clear sky conditions. All LR"s are at $532 \mathrm{~nm}$ except MAO $(355 \mathrm{~nm})$. The standard deviations at each value are about $10-15 \%$.

\section{CONCLUSIONS}

LALINET is in expansion and working to reach good standards and practices for regional monitoring of aerosols and trace gases in South and Central America. The network now comprehends 14 operative stations. The network has been capable of monitoring events under 


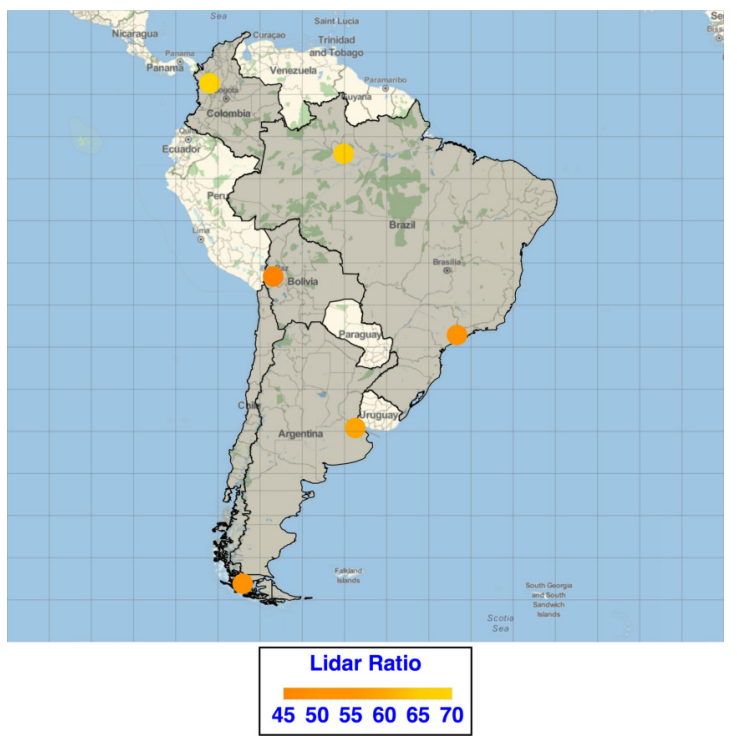

Figure 2: Lidar Ratios at some of LALINET's stations. These values should be updated and extended to other stations in order to have a regional representative values.

a routine and obtaining aerosol optical properties with regional representation and sparse events such as volcanic eruptions. Network capabilities are also under scrunity to comply with $\mathrm{QA} / \mathrm{QC}$ protocols.

\section{ACKNOWLEDGEMENTS}

This work was also partially funded by the University of Granada through the contract Plan Propio. Programa 9. Convocatoria 2013, additional support was given by Universidad Nacional Sede Medellín, NASA-AERONET. FAPESP and CNPq support the brazilian stations.

\section{References}

Antuña-Marrero, J. C., Landulfo, E., Estevan, R., Barja, B., Robock, A., Wolfram, E., ... Guerrero-Rascado, J. L. (2016). LALINET: The first Latin American-born regional atmospheric observational net- work. Bulletin of the American Meteorological Society.

D’Amico, G., Amodeo, A., Baars, H., Binietoglou, I., Freudenthaler, V., Mattis, I., ... Pappalardo, G. (2015). Earlinet single calculus chain - overview on methodology and strategy. Atmospheric Measurement Techniques, 8(11), 4891-4916.

Luis Guerrero-Rascado, J., Landulfo, E., Carlos Antuna, J., Jorge Barbosa, H. d. M., Barja, B., Efrain Bastidas, A., ... Silva, A. (2016). Latin American Lidar Network (LALINET) for aerosol research: Diagnosis on network instrumentation. JOURNAL OF ATMOSPHERIC AND SOLAR-TERRESTRIAL PHYSICS, 138, 112-120.

Mona, L., Arboledas, L. Alados, Amiridis, V., Amodeo, A., Apituley, A., Balis, D., ... Pappalardo, G. (2016). Earlinet: 12-year of aerosol profiling over europe. EPJ Web of Conferences, 119, 19002.

Nishizawa, Tomoaki, Sugimoto, Nobuo, Matsui, Ichiro, Shimizu, Atsushi, Higurashi, Akiko, \& Jin, Yoshitaka. (2016). The asian dust and aerosol lidar observation network (ad-net): Strategy and progress. EPJ Web of Conferences, 119, 19001.

Quel, Eduardo, Sugimoto, Nobuo, Otero, Lidia, Jin, Yoshitaka, Ristori, Pablo, Nishizawa, Tomoaki, ... Mizuno, Akira (2016). Aerosols monitoring network to create a volcanic ash risk management system in argentina and chile. EPJ Web of Conferences, 119, 19006.

Torres, B., Dubovik, O., Fuertes, D., Schuster, G., Cachorro, V. E., Lapionak, T., ... Tanré, D. (2016). Advanced characterization of aerosol properties from measurements of spectral optical depth using the grasp algorithm. Atmospheric Measurement Techniques Discussions, 2016, $1-47$. 